\title{
ARTIs Prevention Efforts at Paya Lebar Village
}

\author{
Nurningsih Sinuraya ${ }^{1}$, Rachmawaty M. Noer ${ }^{2}$, Sherly Mutiara ${ }^{3}$, Endah \\ Hapsari $^{4}$, Neni Triana ${ }^{5}$, Istini ${ }^{6}$ \\ ${ }^{1}$ Tanjung Uban Public Health Centre \\ 2,4,5,6Nursing Science Study Program, STIKes Awal Bros Batam, Indonesia \\ ${ }^{3}$ The Diploma III Midwifery Study Program, STIKes Awal Bros Batam, Indonesia \\ * Corresponding Author : \\ Email: rachmawatymnoer1977@gmail.com
}

\begin{abstract}
.
Acute respiratory tract infection (ARTIS) is an acute respiratory infection that attacks the throat, nose, and lungs that lasts approximately 14 days, ARTIS affects the structure of the channel above the larynx, but most of these diseases affect the upper and lower tracts stimulant or sequentially. (Nurrijal, 2009). According to WHO, ARTIs are the fourth of the 15 million causes of death each year. The number of each year the incidence of ARTIS in Indonesia is 150,000 cases, or it can be said that one person dies every 5 minutes. Activities carried out in the terracelyard of the Tanjung Uban Health Center on Thursday, May 20, 2021, 15.30 - 16.00 WIB. The methods used are lectures and questions and answers. The activity was attended by 15 people representing the KB Village and Paya Lebar Village, Tanjung Uban Village. The people who attended the event were $100 \%$ mothers. With the big role of mothers in the household, it is hoped that the education delivered can benefit the village community and for the family in particular. In providing education, it is carried out using power points, flipcharts, and leaflets. The activity lasts for 30 minutes and conducts discussion and question and answer by presenters and participants who attend. The results of the evaluation to participants by asking some of the materials that have been given, and participants can answer questions from the presenters about ARTIS, its prevention, and treatment at home.
\end{abstract}

Keywords: ARTIs education, prevention and treatment

\section{INTRODUCTION}

Acute respiratory tract infection (ARTIs) is an acute respiratory infection that attacks the throat, nose, and lungs that lasts approximately 14 days, ARTIS affects the structure of the channel above the larynx, but most of these diseases affect the upper and lower tracts stimulant or sequentially. (Nurrijal, 2009).

The term ARTIS includes three important elements, namely infection, respiratory tract, and acute. With the following understanding: infection is the entry of germs or microorganisms into the human body and reproduction to cause symptoms of the disease. The respiratory tract is an organ that extends from the nose to the alveoli along with adnexal organs such as the sinuses, middle ear cavity, and pleura. Thus ARTIS automatically includes the upper respiratory tract, lower respiratory tract (including lung tissue), and respiratory tract adnexal organs. Following this limitation, the lung tissue includes the respiratory tract. Acute infection is an infection that lasts up to 14 
days. The 14-day limit is taken to indicate an acute process although for some diseases that can be classified as ARTIS this process may take more than 14 days. (Ministry of Health, 2010).

According to WHO, ISPA is the fourth of the 15 million causes of death each year. The number of each year I SPA incidents in Indonesia is 150,000 cases or it can be said that a person dies every 5 minutes. In 2007, the prevalence of ARTIS in Indonesia with a symptom diagnosis (DG) was $25.5 \%$, while with a diagnosis by health professionals (D) it was $8.10 \%$. The mortality study in Riskesdas 2007 showed that the proportion of mortality in infants (post-neonatal) due to pneumonia was $23.8 \%$ and in children under five was $15.5 \%$. The high mortality rate due to ARTIS makes us care and can prevent it so that we can avoid the disease. At the time of the initial assessment in Kelurahan Tan Jung Uban, it was found that $79 \%$ had a cold cough in the last 6 months, $13 \%$ of garbage was still burned, $79 \%$ of windows were not opened, $16 \%$ of the distance from the water source from the septic tank $<10$ meters, $15 \%$ open water reservoirs, $23 \%$ littering in rivers/sea, $7 \%$ littering, $17 \%$ of families without landfills / with garbage scattered around, $87 \%$ of open landfills, $34.7 \%$ of landfills $<5$ $\mathrm{m}$ from the house, and $31 \%$ indiscriminate discharge of wastewater. Such behavior can lead to the risk of ARD in the local community. This prompted us to propose conducting community service which aims to educate the public about ARTIS and its prevention. The hope is that the people of Tanjung Uban Urban Village understand ISPA and how to prevent the disease.

\section{METHODS}

Given that it is still in the Covid-19 pandemic period with the implementation of Physical and Social distancing, this activity is carried out at the Tanjung Uban Health Center and is attended by the community on a limited basis. Respondents in this activity are a community in the village of Tanjung Uban, with as many as 15 people. The stages of this activity consist of:

The activity begins with a field survey, the assessment is carried out in Kampung KB and Kampung Paya Lebar. The assessment is carried out by visiting residents' homes and filling out a questionnaire. This activity involved the head of the RT, preceptor from the Puskesmas as the intermediary, and cadres of the Tanjung Uban Health Center. The timing of the assessment will be April 25 - May 1, 2021. 

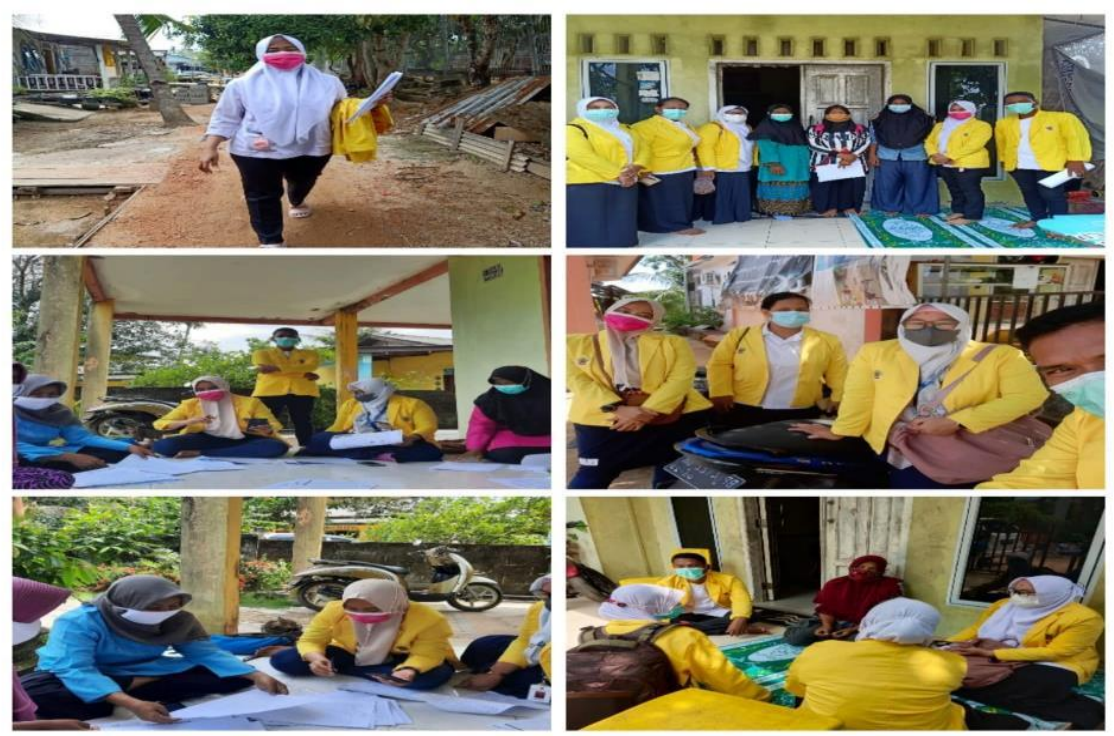

Fig. 1. Field Surveys For Assessment

\section{Outreach and discussion stage}

The extension is carried out offline or face to face with limited communities. Activities carried out in the terrace/yard of the Tanjung Uban Health Center on Thursday, May 20, 2021, 15.30 - 16.00 WIB. The methods used are lectures and questions and answers. In the counseling session, students explained the meaning and causes of respiratory tract infections, signs and symptoms of respiratory tract infections, prevention and treatment efforts. After that the team gave time for discussion and questions and answers with the community present, then the team answered the questions given.

\section{RESULT AND DISCUSSION}

Devotion to the community was conducted by three (3) students, the activity was made directly to the community village of Tanjung Uban. In practice, students explain the meaning and causes of respiratory tract infections, signs and symptoms of respiratory tract infections, prevention and treatment efforts. After that the team gave time for discussion and question and answer with the community present, then the team answered the questions given properly and correctly.

Activities carried out in the terrace/yard of the Tanjung Uban Health Center on Thursday, May 20, 2021, 15.30 - 16.00 WIB. The methods used are lectures and questions and answers. The activity was attended by 15 people representing the KB Village and Paya Lebar Village, Tanjung Uban Village. The people who attended the event were $100 \%$ mothers. With the big role of mothers in the household, it is hoped that the education delivered can benefit the village community and for the family in particular. In providing education, it is carried out using power points, flipcharts, and 
leaflets. The activity lasts for 30 minutes and conducts discussion and question and answer by presenters and participants who attend.
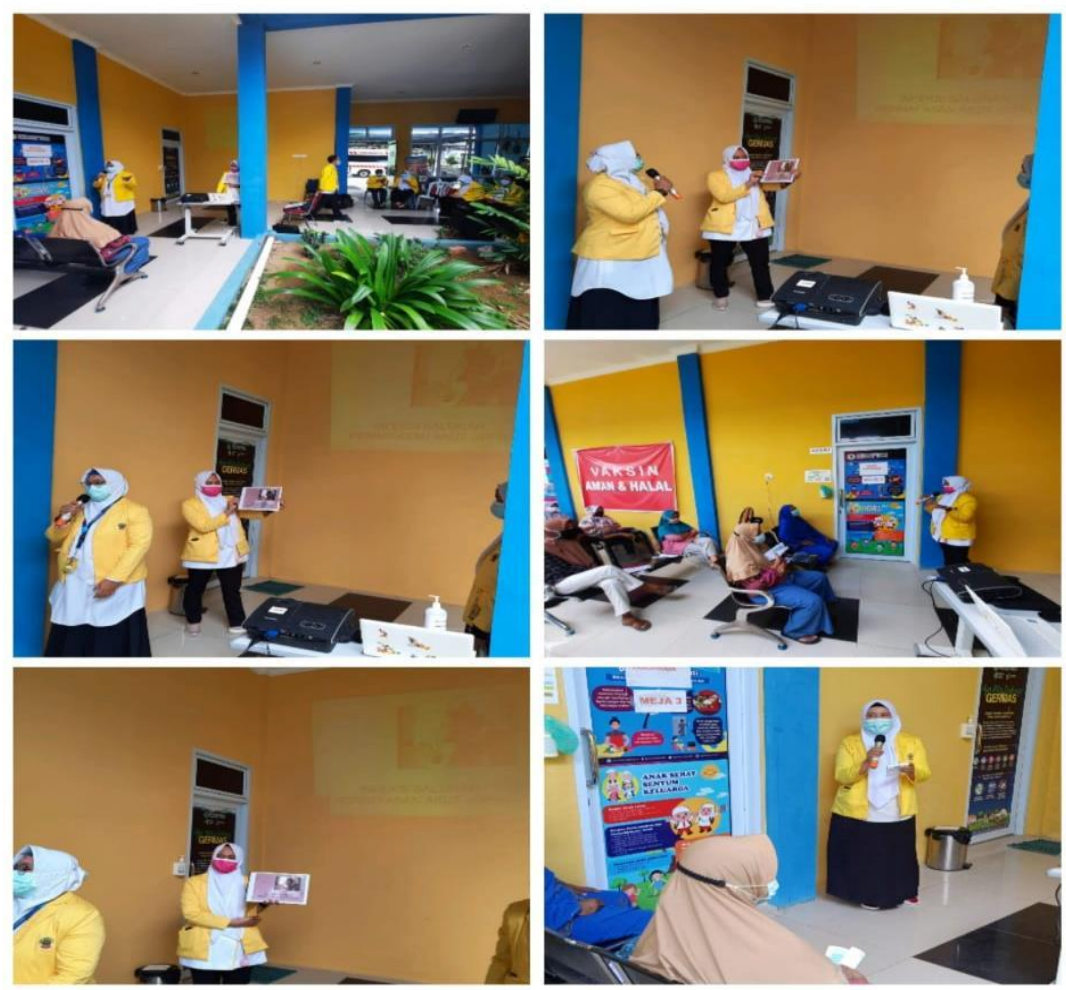

Fig. 2. Presentation of ARTIs Educational

At the beginning of the activity, the presenter explored the level of knowledge of the participants by asking the meaning of ARTIS, several participants answered the question and then the presenter corrected the meaning of ARTIS correctly. After the presenter has finished the presentation, the presenter allows the participants to ask questions. On this occasion, 2 participants asked questions and were answered by the presenter. The answer given by the presenter was satisfactory to the participants. After that, the presenter evaluates the participants by asking some of the material that has been given, and participants can answer questions from the presenters.

The profile of nursing graduates has a major role include the implementation of care services ( care providers), the manager ( manager ), educators ( educator ), communicant good ( communicator), and the last level as a researcher ( researcher ) (Yuningsih, 2016). Related to their role as educators, nurses are required to be able to increase public awareness of the importance of health through health promotion activities. Through health promotion, nurses can provide education to the wider community related to their health problems (Andanawarih \& Baroroh, 2018).

Health promotion media are all means or efforts to display messages or information that the communicator wants to convey. Health promotion cannot be 
separated from the media because through the media, the messages conveyed can be more interesting and understood, so that the target can learn more about these messages so that they decide to adopt positive behavior (Papilaya, 2016).

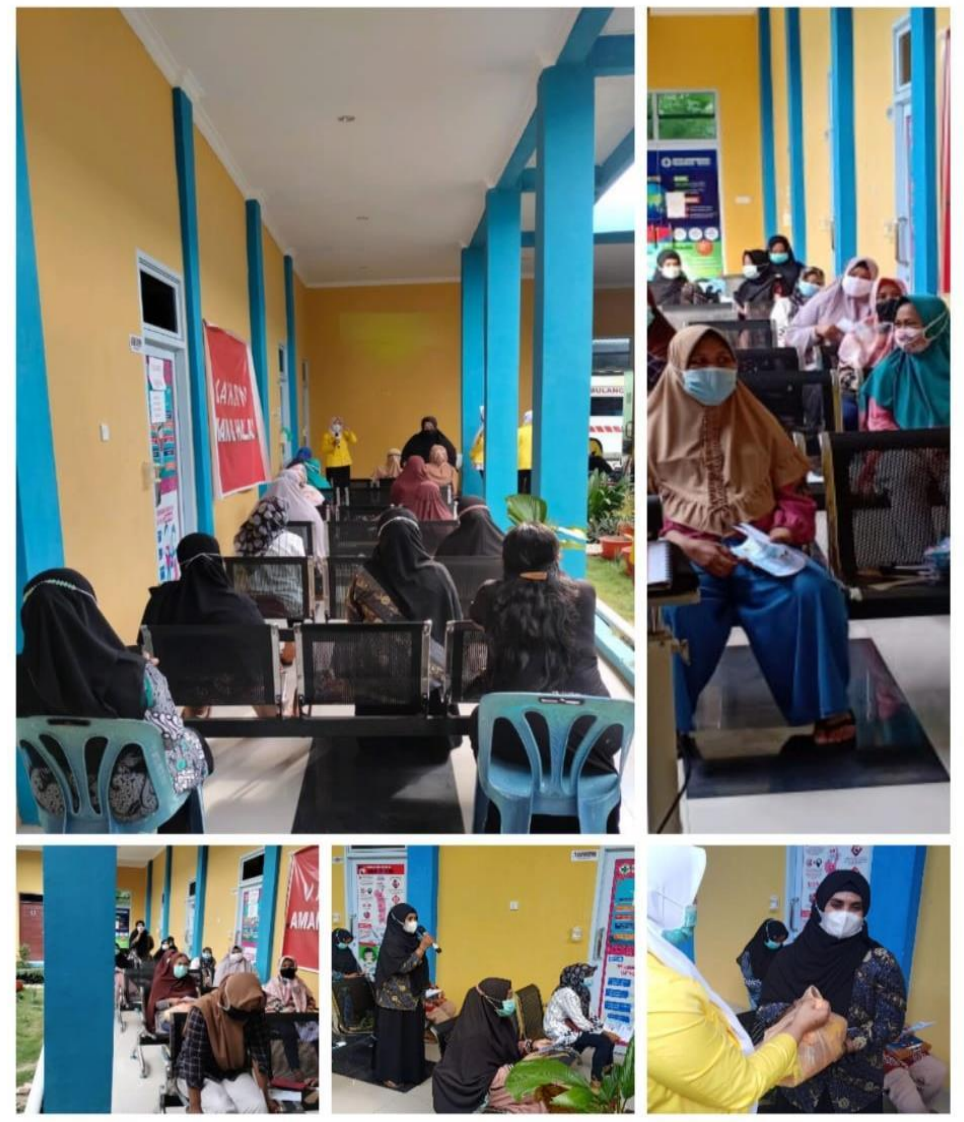

Fig. 3. Activity discussion, question and answer and the division of the public were present doorprise

According to Wina Sanjaya's opinion (2009: 154), the discussion method aims to solve a case or problem, increase or understand knowledge, answer a question, and aim to make a decision. Health promotion media have the advantage of inviting and providing information to the public about ARTISs, how to prevent ARTIS, and its treatment. So that this face-to-face method is very effective in providing education to the public. People are freer to ask any questions without being disturbed by the cellular network so that the intent and message of the educator can be conveyed properly.

The obstacles in this activity are the current situation of the COVID-19 pandemic, so we extension agents cannot invite too many people, to comply with health protocols, one of which is avoiding crowds. Hopefully, in the future, the situation will improve so that in the future it can invite more people and better public knowledge about ISPA. 


\section{CONCLUSION}

The activity carried out on Education About Acute Respiratory Infectious Diseases (ISPA) and Its Prevention in the Community of Tanjung Uban Village, focused on educating the public about ARTIs. Community service activities are carried out in the form of education, transfer of knowledge from students to the community of Tanjung Uban Village. This activity is carried out face-to-face while adhering to the $5 \mathrm{M}$ health protocol (wearing masks, washing hands, keeping distance, staying away from crowds, and limiting mobilization).

At the beginning of the activity, the presenter explored the level of knowledge of the participants by asking the meaning of ARTIS, several participants answered the question and then the presenter corrected the meaning of ARTIS correctly. After the presenter has finished the presentation, the presenter allows the participants to ask questions. On this occasion, 2 participants asked questions and were answered by the presenter. The answer given by the presenter was satisfactory to the participants. After that, the presenter evaluates the participants by asking some of the material that has been given, and participants can answer questions from the presenters.

Suggestions for further community service activities if you are outside the Covid 19 pandemic can invite more people so that more people understand more about ARTIS, its prevention, and treatment. The community can protect their environment well.

\section{ACKNOWLEDGMENTS}

The authors are grateful to the Tanjung Uban Village, STIKes Awal Bros Batam, all of RT 04/RW 07, RT 02 RW 04 Tanjung Uban. We also thank preceptors from STIKes Awal Bros Batam and Tanjung Uban Public Health Centre for the invaluable advice.

\section{REFERENCES}

[1] Andanawarih, P., \& Baroroh, I. (2018). The Role of Midwives as Facilitators for the Implementation of the Maternity Planning and Complication Prevention Program (P4k) in the Pekalongan District Health Center Area. Cycle: Journal of Tegal Polytechnic Midwifery Research, 7 (1) : 252-256.

[2] Ministry of Health of the Republic of Indonesia, 2002, Guidelines for the Eradication of Acute Upper Respiratory Infection for Prevention of Pneumonia in Toddlers in Pelita VI, Ministry of Health of the Republic of Indonesia, Jakarta.

[3] Ministry of Health of the Republic of Indonesia. Riskesdas Indonesia 2007 . jakarta: 2007 .

[4] Ministry of Health of the Republic of Indonesia. 2004. Guidelines for the eradication ofacute respiratory infections (ISPA) to control pneumonia in children under five. Jakarta: MOH RI.

[5] Ministry of Health of the Republic of Indonesia, 2014a, Clinical Practice Guide for Doctors in Primary Health Care Facilities, Ministry of Health of the Republic of Indonesia, Jakarta. 
[6] Ministry of Health of the Republic of Indonesia, 2014b, Indonesia Health Profile 2013 , Ministry of Health of the Republic of Indonesia, Jakarta.

[7] Nurrijal, (2009). Acute Respiratory Infections. http: //www.springerlink.com (23 August 2014 )

[8] Papilaya, EA, ZuliAri, K., \&. J. (2016). Comparison of the effect of health promotion using audio-visual media with audio-visual media on elementary students' oral health behavior. E-TEETH, 4 (2): 282-286.

[9] Sanjaya, Vienna. 2009. Process-Oriented Learning Strategy Standards. Education. Jakarta : Prenada

[10] Somantri, I., 2008, Medical Surgical Nursing: Nursing Care for Patients with Respiratory System Disorders, Salemba Medika, Jakarta.

[11] Susilo, A., Rumende, CM, Pitoyo, CW, Santoso, WD, Yulianti, M., Herikurniawan, H., Sinto, R., Singh, G., Nainggolan, L., Nelwan, EJ, Chen, LK, Widhani, A., Wijaya, E., Wicaksana, B., Maksum, M., Annisa, F., Jasirwan, COM, \& Yunihastuti, E. (2020). 